\title{
Involvement of staphylococcal protein $A$ and cytoskeletal actin in Staphylococcus aureus invasion of cultured human oral epithelial cells
}

\author{
KYU YONG JUNG*\&, JEONG DAN CHA†, SEUNG HYUN LEE‡, WON HONG WOO‡, DO SEON \\ LIM\|, BONG KYU CHOI* and KANG JU KIM†§
}

\begin{abstract}
* Department of Pharmacology, School of Medicine, †Department of Oral Microbiology, College of Dentistry, $\ddagger$ Department of Histology, College of Oriental Medicine and §Center of Oriental Medicinal Science, Wonkwang University, Chonbuk 570-749 and /IDepartment of Dental Hygiene, Seoul Health College, Sungnam, Kyunggi
\end{abstract} 461-250, Korea

\begin{abstract}
Following the coincidental discovery that $\beta$-actin isolated from renal epithelial cells was precipitated by staphylococcal protein A (SPA), the possibility that SPA and cytoskeletal actin filaments may be involved in Staphylococcus aureus infection of epithelial cells was considered. Therefore, to clarify the potential role of SPA and actin filaments in $S$. aureus infection, the invasion efficiency of $S$. aureus was determined quantitatively by measuring the number of cfu of viable organisms recovered from cultured KB cells. $S$. aureus invasion was found to be time dependent (0-60 min) and increased linearly when increasing numbers of bacteria were added $\left(10^{4}-10^{6} \mathrm{cfu} / \mathrm{ml}\right)$. However, significant variation in the level of invasion was noted in protein A-deficient $S$. aureus Wood 46. Cytochalasin B inhibited the invasion efficiency of $S$. aureus in a dose-dependent manner. The present study suggests that interaction of staphylococcal protein $A$ and cytoskeletal actin filaments is involved in the $S$. aureus invasion of cultured $\mathrm{KB}$ cells, and this process may contribute, in part, to the intracellular movement, cell-to-cell spread and dissemination of $S$. aureus within human oral epithelial cells in vivo.
\end{abstract}

\section{Introduction}

While Staphylococcus aureus has not traditionally been considered to be an intracellular pathogen, previous studies have revealed that $S$. aureus cells may be actively internalised by phagocytosis and are capable of intracellular survival in epithelial [1] and endothelial cells $[2,3]$. It has also been suggested that $S$. aureus cells interact or bind with the cell surface of bovine mammary epithelial cells [1] and are able to invade and appear free in the cytoplasm of cultured chicken osteoblast cells [4]. However, little is known of the mechanisms involved in the internalisation of $S$. aureus by the host cells.

On the other hand, it has been suggested that the continuous process of actin filament elongation provides the driving force for bacterial propulsion in infected cells or cytoplasmic extracts [5-7]. Several

Received 5 Jan. 2000; revised version accepted 28 April 2000.

Corresponding author: Dr K.J. Kim (e-mail: kjkimon@ wonkwang.ac.kr). unrelated intracellular bacterial pathogens, including Listeria monocytogenes, Shigella flexneri, rickettsiae and vaccinia virus, are known to share the ability to use actin polymerisation as a driving force for intracellular movement, cell-to-cell spread and dissemination within infected tissues.

Staphylococcal protein A (SPA) is used in a variety of immunological studies by taking advantage of its affinity for the constant $(\mathrm{Fc})$ region of immunoglobulin, because type I Fc receptors are represented in $S$. aureus [8]. Recently, we found that SPA binds to cytoskeletal $\beta$-actin obtained from renal epithelial cells (Fig. 1) (unpublished observation). In an immunoprecipitation study with SPA-immobilised Sepharose 4B (Pharmacia Biotech), a protein (c. $43 \mathrm{kDa}$ in SDS-PAGE) was precipitated by SPA and subjected to Lys-digestion to identify its amino-acid sequence. The SwissProt protein database revealed that the sequences obtained matched those of human $\beta$-actin cytoskeletal protein. This incidental finding led to the conclusion that the binding of SPA to mammalian epithelial actin filaments may play a role in the internalisation or dissemination of $S$. aureus, or both. To clarify this hypothesis, the 


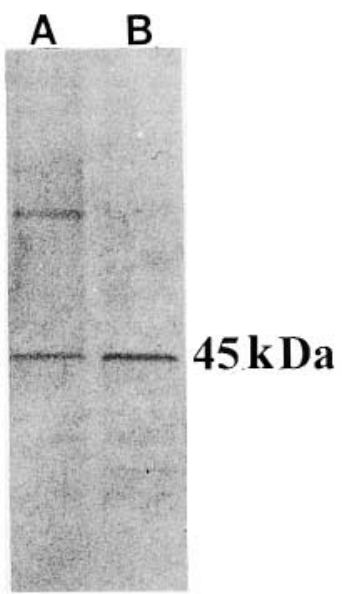

\section{Human $\beta$-actin: LTERGYSFTTTAEREIVRDIK Obtained: LTERGYSFTTTAEREIVRDIK}

Fig. 1. Interaction of staphylococcal protein A with cytoskeletal actin derived from renal epithelial cells. Cell lysates were precipitated with protein A-immobilised Sepharose-4B, and precipitated proteins were electrophoresed in SDS-PAGE 10\%, blotted on polyvinylidine difluoride membrane. The amino-acid sequencing of the protein $(c .43 \mathrm{kDa})$ was determined by the Lys-digestion method. Lane A, staphylococcal protein A plus rabbit antibody; $\mathbf{B}$, staphylococcal protein A alone.

present study examined the potential interaction of SPA and cytoskeletal actin in $S$. aureus infection of cultured human oral epithelial cells.

\section{Materials and methods}

\section{Bacterial strains and growth conditions}

S. aureus ATCC 25923 was purchased commercially. $S$. aureus Wood 46 was kindly supplied by Dr Hideo Igarashi (Tokyo Metropolitan Research Laboratory for Public Health). Before each experiment, a single colony from a blood agar plate (Difco Laboratories, Detroit, MI, USA) was inoculated into a Brain Heart Infusion (BHI, Difco Laboratories) broth and grown overnight at $37^{\circ} \mathrm{C}$ with vigorous shaking. From this culture, $100 \mu \mathrm{l}$ were transferred into $10 \mathrm{ml}$ of BHI broth and incubated for $8 \mathrm{~h}$ at $37^{\circ} \mathrm{C}$ with vigorous shaking. The overnight culture was centrifuged and the pellet was washed once with sterile phosphate-buffered saline (PBS, pH 7.4) and resuspended in the tissueculture medium (without antibiotics; see below) to give a cell density of $10^{5} \mathrm{cfu} / \mathrm{ml}$ unless otherwise specified.

\section{Cell culture}

An established human oral epidermoid carcinoma cell line, designated KB 100, was used. The KB cells were grown routinely in monolayers in Eagle's Minimum Essential Medium (EMEM, Gibco BRL, Grand Island, NY, USA) supplemented with heat-inactivated fetal bovine serum $10 \%$, penicillin G $100 \mathrm{U} / \mathrm{ml}$ and streptomycin sulphate $100 \mu \mathrm{g} / \mathrm{ml}$. Before use, cells were seeded at $5 \times 10^{4}$ cells/well in 24 -well tissue culture plates (Costar, Cambridge, MA, USA) for binding and invasion assays and grown into confluent monolayers for 2 days in air at $37^{\circ} \mathrm{C}$ with $\mathrm{CO}_{2} 5 \%$.

\section{Adherence and invasion assay}

For bacterial adherence and invasion in cultured monolayers of $\mathrm{KB}$ cells, the methods of Isberg and Falkow [9] and Bayles et al. [1] were used with some modifications. Briefly, c. $16 \mathrm{~h}$ before beginning the experiment, the $\mathrm{KB}$ cells were washed three times with invasion medium (growth medium without serum and antibiotics) and held in this medium. Just before beginning the experiment, the medium was removed and the $\mathrm{KB}$ cell monolayers were washed once with invasion medium followed by a further addition of $1 \mathrm{ml}$ of fresh invasion medium. Appropriate wells of $\mathrm{KB}$ cells were inoculated with $1 \mathrm{ml}$ of invasion medium containing $10^{5} \mathrm{cfu} / \mathrm{ml} /$ well (or other doses) of bacteria for the specified times at $37^{\circ} \mathrm{C}$ in air with $\mathrm{CO}_{2} 5 \%$. Subsequently, the medium was removed from the infected monolayers, before washing three times with sterile $\mathrm{Ca}^{2+}$ - and $\mathrm{Mg}^{2+}$-free $\mathrm{PBS}$ to remove nonadherent bacteria. The KB cell monolayers were treated with trypsin $0.25 \%$ in Hanks's Balanced Salts Solution (Gibco BRL) and further lysed with Triton X-100 (Sigma) $0.025 \%$ in sterile distilled water. Cell lysates were serially diluted 20 -fold and plated in triplicate on blood agar plates; the plates were then incubated overnight at $37^{\circ} \mathrm{C}$ and the cfu were counted. At this time, colonies of $S$. aureus were identified by Gram's staining, catalase and coagulase tests. To quantify membrane-adherent and intracellular bacteria, gentamicin was used to kill any extracellular bacteria [10]. After the KB cell monolayers had been incubated with bacteria for the specified times at $37^{\circ} \mathrm{C}$ in air with $\mathrm{CO}_{2}$ $5 \%$, supernates were removed and replaced with $1 \mathrm{ml}$ of medium containing gentamicin (Gibco BRL), $100 \mu \mathrm{g} / \mathrm{ml}$ followed by incubation at $37^{\circ} \mathrm{C}$ with $\mathrm{CO}_{2}$ $5 \%$. After $2 \mathrm{~h}$, the supernates were removed and discarded. The KB cell monolayers were washed three times with sterile PBS, and any intracellular bacteria were recovered and counted as described previously.

\section{Treatment with cytochalasin}

To examine whether inhibition of bacterial invasion by cytochalasin $\mathrm{B}(\mathrm{CB})$ could occur, an invasion assay was done as described above, in the presence or absence of CB (Sigma). KB cell monolayers were incubated with normal growth medium containing $\mathrm{CB}$ at a given concentration for $30 \mathrm{~min}$ at $37^{\circ} \mathrm{C}$ in air with $\mathrm{CO}_{2} 5 \%$, followed by incubation of the KB cell monolayers with $S$. aureus $\left(1 \times 10^{5} \mathrm{cfu} / \mathrm{ml}\right)$ in the presence of the same concentration of $\mathrm{CB}$.

\section{Electron microscopy}

Transmission electron microscopy (TEM) was used to visualise $S$. aureus invasion of KB cells. The invasion 
assay remained similar except that gentamicin was not added to the co-culture. The procedure for tissue processing was slightly modified from the procedures of Bayles et al. [1]. The infected cells were placed in glutaraldehyde $3 \%$ in $0.1 \mathrm{M}$ cacodylate buffer containing sucrose $6 \%$. Cells were post-fixed with osmium tetroxide $2 \%$ for $1 \mathrm{~h}$. Cells were then scraped off the culture flask, centrifuged briefly and embedded in agar $1.5 \%$. Small cubes of the agar were dehydrated, embedded in Epson/Spurrs resin mixture; 100-nm sections were cut with glass knives. After counterstaining with uranyl acetate $0.5 \%$ and lead citrate $1.0 \%$, sections were examined by transmission electron microscopy (TEM; Zeiss, EM910).

\section{Results}

\section{Effect of cell numbers and time on $S$. aureus invasion of $K B$ cells}

To measure the efficiency of $S$. aureus infection of oral epithelial cells, the effects of different cell numbers and time on $S$. aureus invasion of KB cell monolayers were first examined by measuring the numbers of bacterial cells adhering to cells or becoming intracellular. When monolayers were incubated for $30 \mathrm{~min}$ with different numbers of bacteria $\left(1 \times 10^{4}, 10^{5}\right.$ and $\left.10^{6} \mathrm{cfu} / \mathrm{ml}\right)$, an increase in the inoculum size resulted in an increase in the number of cfu recovered (Fig. 2a). Longer incubation times resulted in an increase in the number of cfu recovered (Fig. 2b). The cfu recovered increased in a time-dependent manner and approached $28.6 \%$ by $60 \mathrm{~min}$, i.e., the percentage of the original inoculum which became bound and invaded the host cell membrane. TEM confirmed these results and clearly showed intracellular $S$. aureus in cultured oral epithelial cells (Fig. 3). Furthermore, treatment with lysostaphin (20 and $40 \mu \mathrm{g} / \mathrm{ml}$ ) dramatically reduced

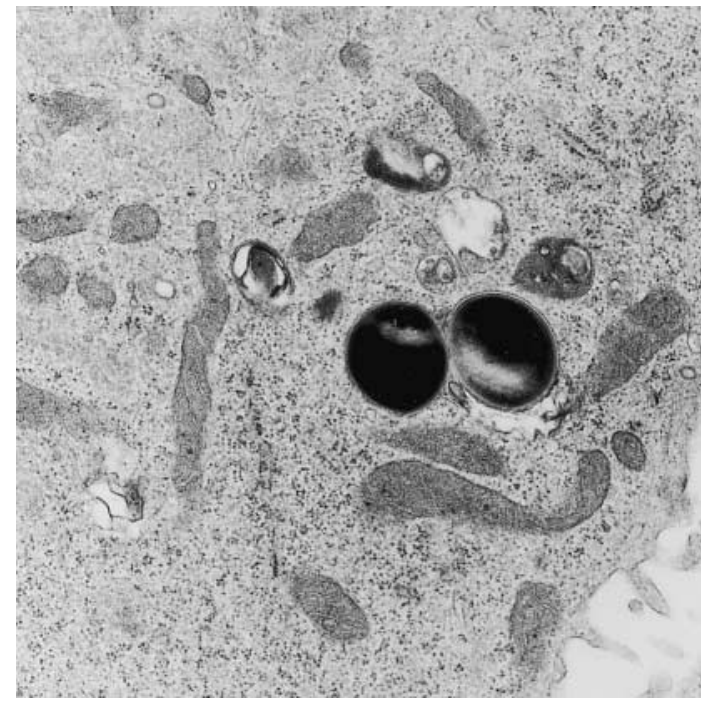

Fig. 3. Transmission electron microscopy of KB cells infected with $S$. aureus ATCC 25923. Photograph represents a 60-min co-culture of cell monolayers with $S$. aureus as described in the invasion assay (magnification $\times 10000)$.

the numbers of $S$. aureus recovered from cell monolayers (data not shown).

\section{S. aureus invasion of $K B$ cells}

Further studies were conducted to differentiate between $S$. aureus adhesion and invasion of $\mathrm{KB}$ cells by using gentamicin treatment to kill adherent bacteria. Bacterial invasion of $\mathrm{KB}$ cells was estimated by quantifying the number of intracellular bacteria protected from gentamicin killing. Monolayers were incubated with S. aureus $\left(1 \times 10^{5} \mathrm{cfu} / \mathrm{ml}\right)$ for $30 \mathrm{~min}$, followed by coculture in the presence of gentamicin $100 \mu \mathrm{g} / \mathrm{ml}$ with or without $\mathrm{CB}(0.1-5 \mu \mathrm{g} / \mathrm{ml})$ for $30 \mathrm{~min}$ (Fig. 4). CB decreased the numbers of $S$. aureus protected from
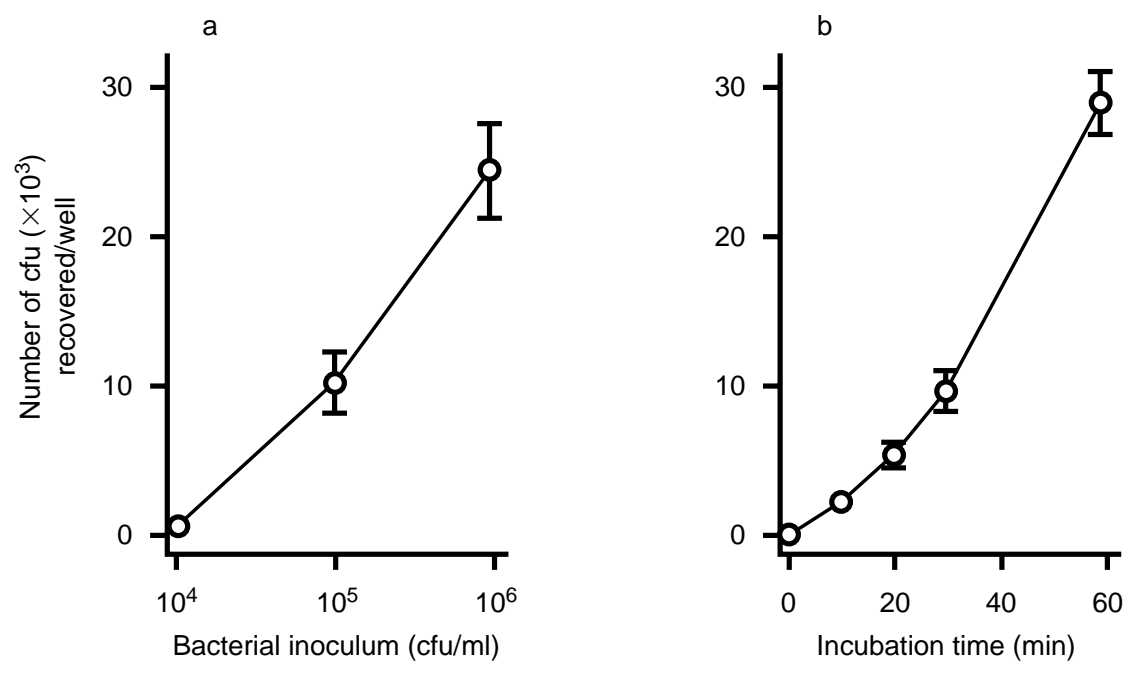

Fig. 2. Kinetics of S. aureus ATCC 25923 infection of KB cells. Monolayers were incubated with different numbers of bacteria for $30 \mathrm{~min}$ (a) or $10^{5} \mathrm{cfu} / \mathrm{ml}$ for the specified times (b), followed by measurement of colony forming units (cfu) recovered from cell monolayers. Each point represents means and SEM from 8 or 10 determinations done in triplicate. 


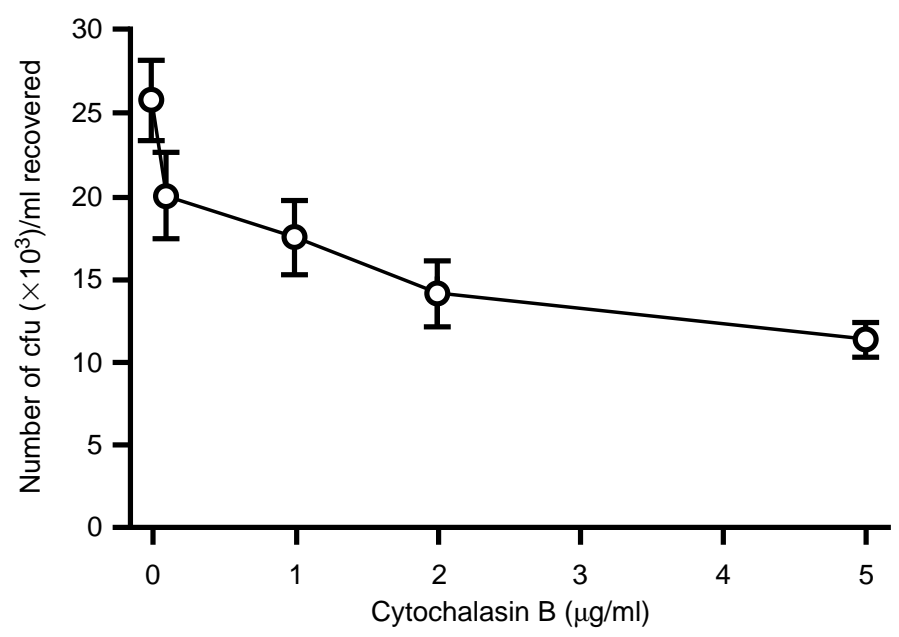

Fig. 4. Dose-response of cytochalasin B on S. aureus ATCC 25923 invasion of KB cells. Cell monolayers were cultured with $S$. aureus $\left(10^{5} \mathrm{cfu} / \mathrm{ml}\right)$ for $30 \mathrm{~min}$ and washed three times with $\mathrm{Ca}^{2+}$ - and $\mathrm{Mg}^{2+}$-free PBS to remove non-adherent bacteria, followed by additional co-culture in the presence of gentamicin with or without various concentrations of cytochalasin B for $30 \mathrm{~min}$. Each point represents means and SEM from 8 or 10 determinations done in triplicate.

gentamicin killing in a dose-dependent manner; $\mathrm{CB}$ $1 \mu \mathrm{g} / \mathrm{ml}$ caused c. $50 \%$ decrease of the initially inoculated numbers of $S$. aureus $\left(25.7 \times 10^{3} \mathrm{cfu} / \mathrm{ml}\right)$. However, cytochalasin D (CD) did not significantly change the numbers of $S$. aureus protected from gentamicin killing (data not shown).

In further experiments, cell monolayers were inoculated with $S$. aureus $1 \times 10^{5} \mathrm{cfu} /$ well for the specified times and co-cultured for $2 \mathrm{~h}$ in the presence of gentamicin with and without CB (Fig. 5a). The recovered cfu of $S$. aureus in the absence of $\mathrm{CB}$ increased in a timedependent manner and approached $17.4 \%$ by $60 \mathrm{~min}$. In comparison, $\mathrm{CB}$ inhibited the numbers of $S$. aureus recovered from $\mathrm{KB}$ cells within $20 \mathrm{~min}(\mathrm{p}<0.01)$.
To confirm these results by means of different strategies, the $\mathrm{KB}$ cell monolayers were exposed to $S$. aureus $1 \times 10^{5} \mathrm{cfu}$ for $30 \mathrm{~min}$ and co-cultured for several different time periods in the presence of gentamicin with and without CB. As shown in Fig. $5 \mathrm{~b}$, the number of cfu of $S$. aureus recovered after exposure to gentamicin was decreased by co-culture, and the decrease in cfu was sustained from $30 \mathrm{~min}$ to $2 \mathrm{~h}(\mathrm{p}<0.01)$.

\section{Effect of protein $A$ on $S$. aureus invasion}

To determine the role of SPA in $S$. aureus invasion of $\mathrm{KB}$ cells, cell monolayers were incubated with wildtype (ATCC 25923) and protein A-deficient S. aureus
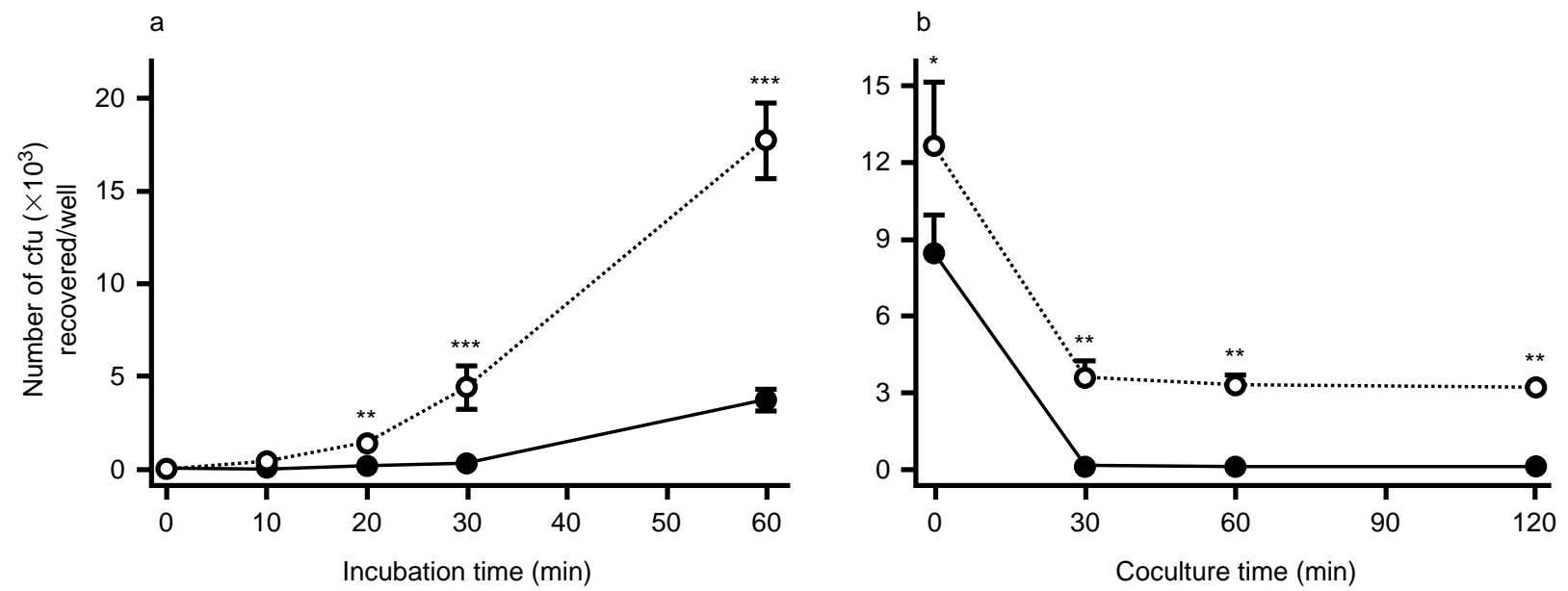

Fig. 5. Inhibition of $S$. aureus ATCC 25923 invasion of KB cells by cytochalasin B. (a) Cell monolayers were incubated with $S$. aureus $10^{5} \mathrm{cfu} / \mathrm{ml}$ for several different time intervals, followed by additional co-culture with $(\bullet)$ and without (O) cytochalasin B $1 \mu \mathrm{g} / \mathrm{ml}$ plus gentamicin for $2 \mathrm{~h}$. (b) Cells were incubated with $S$. aureus $10^{5} \mathrm{cfu} / \mathrm{ml}$ ) for $30 \mathrm{~min}$, followed by additional co-culture with $(\bullet)$ and without $(\mathrm{O})$ cytochalasin $\mathrm{B}(1 \mu \mathrm{g} / \mathrm{ml})$ plus gentamicin for several time periods. Each point represents mean and SEM of cfu from eight separate experiments done in triplicate. 
Wood $461 \times 10^{5} \mathrm{cfu} / \mathrm{ml}$ for the specified times, followed by co-culture with gentamicin for $2 \mathrm{~h}$. As shown in Fig. 6, the numbers of strain ATCC 25923 recovered from cell monolayers increased in a timedependent manner. However, the invasion efficiency $(0.1-1.5) \times 10^{3} \mathrm{cfu} / \mathrm{ml}$ of $S$. aureus Wood 46 remained low throughout the incubation period. At $60 \mathrm{~min}$, the numbers of strain Wood 46 recovered was only $7 \%$ of that of wild-type $S$. aureus ATCC 25923.

The invasion efficiency of $S$. aureus for cultured KB cells was estimated by determining bacterial numbers protected from gentamicin killing for $2 \mathrm{~h}$ [11]. As shown in Table 1, invasion efficiency increased during incubation; $\mathrm{CB} 1 \mu \mathrm{g} / \mathrm{ml}$ dramatically reduced its invasion efficiency. The invasion efficiency of protein A-deficient $S$. aureus Wood 46 was much lower than that of wild-type $S$. aureus.

\section{Discussion}

The present study provides evidence that SPA and cytoskeletal actin filaments feature in $S$. aureus invasion of human oral epithelial cells. $\mathrm{KB}$ cells were used as a model for gingival epithelial cells because they are known to be suitable for investigating bacterial interactions in vitro $[11,12]$. The results suggest that cytoskeletal actin in epithelial cells binds to SPA of $S$. aureus; $S$. aureus may adhere to and invade oral epithelial cells through interaction with SPA and actin filaments and $S$. aureus internalisation by oral epithelial cells may be mediated by polymerisation of actin filaments, which is a CB-sensitive process.

An immunoprecipitation assay with SPA-immobilised Sepharose 4B found that SPA precipitates a protein $(c$. $43 \mathrm{kDa}$ ) which has a high homology with human $\beta$ actin. This in-vitro finding suggests that SPA has a binding affinity with cytoskeletal actin filaments of mammalian epithelial cells in vivo, and this process may be involved in the pathogenesis and invasion or internalisation, or both, of $S$. aureus. Although there is no direct evidence suggesting that either mammalian actin filaments contain an SPA-binding domain, or that actin receptors are found in the surface of $S$. aureus, it is possible that the binding of SPA and actin filaments may regulate $S$. aureus infection of mammalian epithelial cells. This suggestion may be related, in part, to the previous report that intracellular pathogens develop a common mechanism to exploit the actin cytoskeleton as a means of facilitating their direct spread between cells [13].

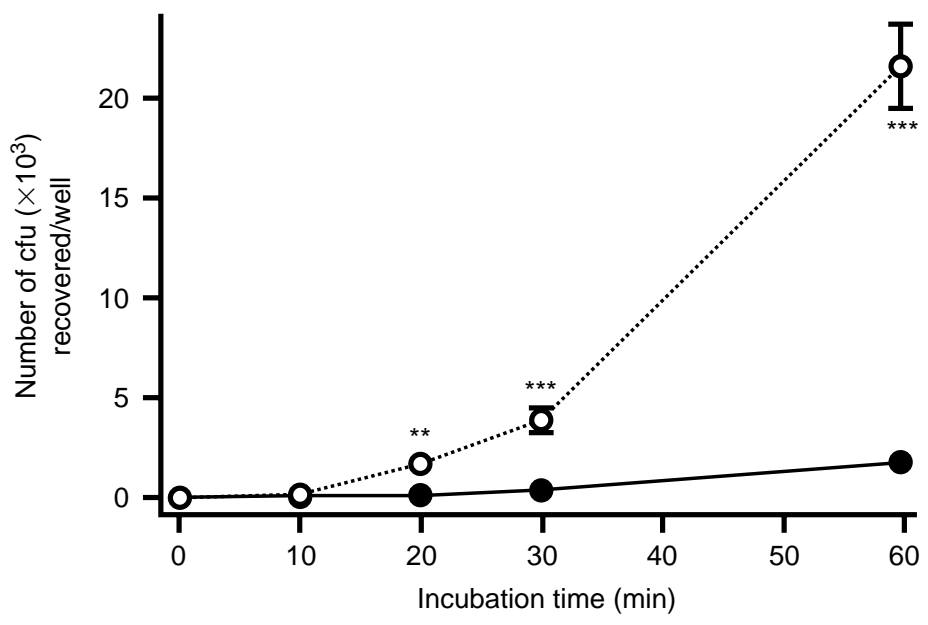

Fig. 6. Efficiency of S. aureus ATCC 25923 (○) and Wood 46 (•) invasion of KB cells. Monolayers were infected with $10^{5} \mathrm{cfu} / \mathrm{ml} /$ well of each strain for specified times, followed by additional co-culture for $2 \mathrm{~h}$ in the presence of gentamicin. Each point represents mean and SEM of cfu from eight separate experiments carried out in triplicate.

Table 1. Comparison of invasion efficiency of S. aureus strains ATCC 25923 and Wood $46\left(10^{3}\right.$ cfu) for cultured KB cells

\begin{tabular}{|c|c|c|c|c|}
\hline \multirow[b]{2}{*}{ Culture conditions } & \multicolumn{4}{|c|}{ Intracellular bacteria $\left(10^{3} \mathrm{cfu} / \mathrm{ml}\right)$ after incubation for $(\mathrm{min})$} \\
\hline & 10 & 20 & 30 & 60 \\
\hline $\begin{array}{l}\text { S. aureus ATCC } 25923 \text { before gentamacin killing } \\
\text { after gentamicin killing }\end{array}$ & $2.1(0.22)$ & $5.2(0.85)$ & $9.4(1.37)$ & $28.6(2.12)$ \\
\hline without cytochalasin B & $0.3(0.06)$ & $1.3(0.34)$ & $4.2(1.19)$ & $17.4(2.07)$ \\
\hline with cytochalasin B & $0.04(0.01)$ & $0.08(0.01)$ & $0.2(0.03)$ & $3.4(0.59)$ \\
\hline $\begin{array}{l}\text { S. aureus Wood } 46 \text { after gentamacin killing } \\
\text { (without cytochalasin B) }\end{array}$ & $0.01(0.01)$ & $0.04(0.01)$ & $0.3(0.08)$ & $1.5(0.48)$ \\
\hline
\end{tabular}

$\mathrm{KB}$ cell monolayers were incubated with $10^{5} \mathrm{cfu} / \mathrm{ml}$ of bacteria for each time period and washed three times with $\mathrm{Ca}^{2+}-$ and $\mathrm{Mg}^{2+}-\mathrm{free} \mathrm{PBS}$, followed by additional co-culture with gentamicin $100 \mu \mathrm{g} / \mathrm{ml}$ for $2 \mathrm{~h}$ and the numbers of cfu protected from gentamicin killing were counted. Values represent the means (ZM) SE of 8-10 determinations made in triplicate 
Bacterial adhesion is typically mediated through the interaction of bacterial ligands with the surface characteristics of host cells [14-16]. For example, extracellular matrix molecules, i.e., fibronectin, vitronectin, laminin and type IV collagen, can participate in the normal colonisation of sites by micro-organisms and in invasion during infections [17-19]. The role of cytoskeletal molecules, i.e., actin filaments, in invasion and internalisation of micro-organisms in mammalian cells has also been demonstrated $[6,7,13,19-21]$. The invasion efficiency of protein A-expressing and -deficient $S$. aureus strains was significantly different. These differences suggest that unknown de novo processes may be involved in $S$. aureus infection in mammalian epithelial cells.

It has been shown that inhibition of actin elongation by CB $[21,22]$ concomitantly significantly inhibited the invasion of cultured $\mathrm{KB}$ cell monolayers by $S$. aureus. A similar result was also reported in renal epithelial cells [22]. It is possible that $\mathrm{CB}$ did not directly inhibit $S$. aureus invasion of cell monolayers, because the concentration of $\mathrm{CB}$ used in the present study had no apparent inhibitory effect on endocytosis of other micro-organisms [23]. Several pathogenic intracellular bacteria, including L. monocytogenes, Shigella and Rickettsia spp., use host cell actin cytoskeleton for propulsion [20, 23, 24]. These suggestions indicate that protein A may be necessary for binding of $S$. aureus to cytoskeletal actin filaments of $\mathrm{KB}$ cells.

It is generally considered that several factors, including the infective dose, regulate bacterial invasion of mammalian cells, i.e., high levels of infecting inocula are required to elicit invasion by micro-organisms that produce more chronic infections [10]. This seems to suggest that any bacterium may invade mammalian cell monolayers, if the infecting inoculum is sufficiently high. However, in the present study it was observed that the invasion efficiency of $S$. aureus Wood 46 was not increased, even when the bacterial inoculum level was increased (Fig. 6). A similar phenomenon has been observed in Haemophilus aprophilus in cultured human oral epithelial cells [11]. In cultured bovine aortic endothelial cells, S. aureus-induced cytotoxicity depended on the size of inoculum and the length of incubation [3]. This may be due to intracellularisation of $S$. aureus and is consistent with the results obtained here (Fig. 2). No cytotoxicity induced by treatment of KB cells with $S$. aureus for $120 \mathrm{~min}$ was observed in the MTT assay (data not shown). The need for a high infective dose for invasion may indicate a different invasion tactic. The kinetics of $S$. aureus adhesion/ invasion to $\mathrm{KB}$ cells revealed that a lag period occurred, suggesting that a factor or component involved in triggering invasion may have to attain a critical concentration for optimal invasion to occur. Furthermore, possible factors involved in $S$. aureus invasion may include bacterial and cellular metabolites or cellsurface receptors that have not been identified as yet.
In conclusion, this study has demonstrated that SPA has a binding affinity for epithelial actin filaments, and this is involved in the regulation of $S$. aureus invasion and internalisation by oral epithelial cells. Elongation of actin filaments by their polymerisation may mediate this process and thereby provide a novel regulatory role in $S$. aureus infection of oral epithelial cells. Similar types of in-vivo modulation caused by staphylococcal protein A and epithelial actin cytoskeleton may contribute to the pathogenesis of $S$. aureus infections.

This work was supported in part by a Research Grant (\#1999-214-00001-1) from the Korea Science and Engineering Foundation and Wonkwang University Research Fund in 2000.

\section{References}

1. Bayles KW, Wesson CA, Liou LE, Fox LK, Bohach GA, Trumble WR. Intracellular Staphylococcus aureus escapes the endosome and induces apoptosis in epithelial cells. Infect Immun 1998; 66: 336-342.

2. Blumberg EA, Hatcher VB, Lowy FD. Acidic fibroblast growth factor modulates Staphylococcus aureus adherence to human endothelial cells. Infect Immun 1988; 56: 1470-1474.

3. Vann JM, Proctor RA. Ingestion of Staphylococcus aureus by bovine endothelial cells results in time- and dose-dependent damage to endothelial cell monolayers. Infect Immun 1987; 55: 2155-2163.

4. Hudson MC, Ramp WK, Nicholson NC, Williams AS, Nousiainen MT. Internalization of Staphylococcus aureus by cultured osteoblasts. Microb Pathog 1995; 19: 409-419.

5. Cudmore S, Cossart P, Griffiths G, Way M. Actin-based motility of vaccinia virus. Nature 1995 ; 378: 636-638.

6. Lasa I, Cossart P. Actin-based bacterial motility: towards a definition of the minimal requirements. Trends Cell Biol 1996; 6: $109-114$.

7. Lasa I, Gouin E, Goethals $\mathrm{M}$ et al. Identification of two regions in the $\mathrm{N}$-terminal domain of ActA involved in the actin comet tail formation by Listeria monocytogenes. EMBO J 1997; 16: 1531-1540.

8. Eliasson M, Olsson A, Palmcrantz E et al. Chimeric IgGbinding receptors engineered from staphylococcal protein A and staphylococcal protein G. J Biol Chem 1988; 263: 4323-4327.

9. Isberg RR, Falkow S. A single genetic locus encoded by Yersinia pseudotuberculosis permits invasion of cultured animal cells by Escherichia coli K-12. Nature 1985; 317: $262-264$

10. Ewanowich CA, Melton AR, Weiss AA, Sherburne RK, Peppler MS. Invasion of HeLa 229 cells by virulent Bordetella pertussis. Infect Immun 1989; 57: 2698-2704.

11. Meyer DH, Sreenivasan PK, Fives-Taylor PM. Evidence for invasion of a human oral cell line by Actinobacillus actinomycetemcomitans. Infect Immun 1991; 59: 2719-2726.

12. Mintz KP, Fives-Taylor PM. Adhesion of Actinobacillus actinomycetemcomitans to a human oral cell line. Infect Immun 1994; 62: 3672-3678.

13. Buxton TB, Rissing JP, Horner JA et al. Binding of Staphylococcus aureus bone pathogen to type I collagen. Microb Pathog 1990; 8: 441-448.

14. Oho T, Yu H, Yamashita Y, Koga T. Binding of salivary glycoprotein-secretory immunoglobulin A complex to the surface protein antigen of Streptococcus mutans. Infect Immun 1998; 66: 115-121.

15. Shuter J, Hatcher VB, Lowy FD. Staphylococcus aureus binding to human nasal mucin. Infect Immun 1996; 64: $310-318$.

16. Vaudaux P, Suzuki R, Waldvogel FA, Morgenthaler JJ, Nydegger UE. Foreign body infection: role of fibronectin as a ligand for the adherence of Staphylococcus aureus. J Infect Dis 1984; 150: 546-553.

17. Vercellotti GM, McCarthy JB, Lindholm P, Peterson PK, Jacob HS, Furcht LT. Extracellular matrix proteins (fibronectin, 
laminin, and type IV collagen) bind and aggregate bacteria. Am J Pathol 1985; 120: 13-21.

18. Paulsson M, Petersson A-C, Ljungh A. Serum and tissue protein binding and cell surface properties of Staphylococcus lugdunensis. J Med Microbiol 1993; 38: 96-102.

19. Smith GA, Portnoy DA, Theriot JA. Asymmetric distribution of the Listeria monocytogenes ActA protein is required and sufficient to direct actin-based motility. Mol Microbiol 1995; 17: $945-951$.

20. Welch MD, Iwamatsu A, Mitchison TJ. Actin polymerization is induced by Arp $2 / 3$ protein complex at the surface of Listeria monocytogenes. Nature 1997; 385: 265-269.

21. Toyama S, Toyama S. Functional alterations in $\beta$ '-actin from a
KB cell mutant resistant to cytochalasin B. J Cell Biol 1988; 107: $1499-1504$.

22. Murai M, Seki K, Sakurada J, Usui A, Masuda S. Effects of cytochalasins B and D on Staphylococcus aureus adherence to and ingestion by mouse renal cells from primary culture. Microbiol Immunol 1993; 37: 69-73.

23. Goldberg MB, Theriot JA. Shigella flexneri surface protein IcsA is sufficient to direct actin-based motility. Proc Natl Acad Sci USA 1995; 92: 6572-6576.

24. Heinzen RA, Hayes SF, Peacock MG, Hackstadt T. Directional actin polymerization associated with spotted fever group Rickettsia infection of Vero cells. Infect Immun 1993; 61: 1926-1935. 